\title{
Classification of Student Reasoning Skills in Solving Mathematics Problems in Elementary School
}

\author{
Joko Sulianto ${ }^{*}$, Sunardi ${ }^{2}$, Sri Anitah ${ }^{3}$, Gunarhadi $^{4}$ \\ ${ }^{1}$ Student in Education Science Departement, Sebelas Maret University, Surakarta. \\ 2,3,4Education Science Departement, Sebelas Maret University, Surakarta. \\ e-mail: sulianto.jo@gmail.com, nardi_ip@uns.ac.id,gunarhadi@fkip.uns.ac.id
}

\begin{abstract}
The purpose of this study was to describe the classification of students' reasoning skills in solving mathematical problems in elementary schools. The focus of this study is the classification of students' reasoning skills in solving mathematical problems in the elementary schools. The approach used in this study is a qualitative approach. Research subject are elementary school students. Data was taken using tests. Based on data analysis, the reasoning classification is as follows: $36.25 \%$ understand the meaning in low categories, 37.5\% think logically in low categories, $31.1 \%$ understand negative examples in low categories, $17.05 \%$ think deductions in very low category, $18.15 \%$ think systematically in very low categories, $31.65 \%$ think consistently in low category, $34.85 \%$ make excuses and determine strategies in low category, $49.85 \%$ determine method in low category, and $24.3 \%$ draw conclusions in low category. Thus the reasoning ability of students is low, students have not been able to think logically to make connections between empirical facts and the problems faced so they are not able to draw conclusions, students have not been able to make new arguments or statements based on facts, Learning models need to be developed to enhance the reasoning skills of elementary school students.
\end{abstract}

Keywords: Classification; Reasoning; Mathematical Problem-Solving

\section{Introduction}

Changes in 21st-century society students must have the skills to understand and apply ICT literacy skills. education plays a very significant and strategic role in developing educated communities with skills such as (1) technology and media literacy; (2) constructive communication; (3) critical thinking; (4) problem solving; and (5) collaborative communication. One of the skills of the 21 st century is skills in learning and innovation, that is to say problem-solving. Problem-solving is a high-level thought skill that can be built in elementary schools by studying mathematics. Problem-solving skills are learned by elementary school students not only in quantitative problem-solving skills but by mathematical thinking, students may solve problems in other fields. Hino (2007) mathematical problem solving has helped (1) to deepen and broaden our knowledge of students' thinking and learning mathematics processes, (2) to stimulate our efforts to develop materials and effective ways to organize problem-solving lessons, and (3) to provide a powerful tool for assessing students' thinking and attitude. Moursund (2005) says that when faced with the following 4 conditions, an individual is considered to have and face problems: (1) clearly understand the condition or circumstance that is occurring; (2) clearly understand the goals predicted. Use a range of goals to solve problems that can contribute to one resolution goal; (3) consider a collection of tools that can be used to resolve challenges that arise according to the desired objectives. This includes time, information, expertise, technology, or specific items, (4) possesses the ability to use various resources to achieve objectives.

Shadiq (2008) Questions can only become a problem if the argument presents a difficulty that can not be solved by a routine procedure known to the student, so solving a problem takes a comparatively longer time than the ordinary routine problem-solving

\footnotetext{
* Corresponding author.

Received 20 January 2020; Accepted 13 March 2020; Available online 31 March 2020 (c) 2020 JPI. All Rights Reserved
} 
process. To be able to solve a problem, there are four important steps that must be completed: (1) understand the problem, in this step, students must be able to determine accurately what is known and what is asked. But keep in mind, the ability of the human brain is very limited, so important things should be noted, made the table, or made graphs or sketches. This table or chart aims to make it easier to grasp the problem and to provide an outline of the solution. By making drawings, diagrams or tables, things that are known are not only imagined in the brain which is very limited in ability, but can be poured on paper, (2) planning how to solve it, to solve what problems must be done? Will it do with trial and error? but what if a combination of numbers is passed? to avoid this, it is necessary to have rules made by the actors themselves during the problem solving process so that it can be ascertained that no alternative has been overlooked, (3) implementing the plan, meaning that every step that has been we plan to do it in this section in accordance with established procedures, (4) interpret the results, the step of looking back to see whether the settlement we have obtained is in accordance with known provisions and no contradiction is an important last step.

The direction of the Ministry of Education and Culture's new policy on freedom of learning on numerical content is the ability to reason using mathematics. Standards in school mathematics include material standards (mathematical material) and process standards (mathematical processes); process standards include problem-solving, reasoning, and communication (Arianto, Sulianto, \& Azizah; 2019). Establishing reasoning as one of the skills in the standard process demonstrates that reasoning skills are one of the important aspects that students must have in the learning process. The National Council of Mathematics Teachers (NCTM) notes that the basic skills and understanding required by students in the 21st century are both material standards and process standards (the standards together define the basic skills and understandings that students would need to work effectively in the 21st century. Improving the standard of students can be achieved by teachers by increasing the quality of learning in the classroom with high-level thinking skills driven. The process of improving the quality of learning in an effort to improve the quality of students and eventually improve the quality of education in Indonesia. Learning models that develop learning-oriented to student reasoning are needed. The aim is to improve the quality of learning which ultimately improves the quality of students. (Ariyana, from 2019: 1).

The aim of this study is to describe the classification of student reasoning in primary school problem-solving. To be able to think critically and solve problems, the learning process is conducted interactively, enjoyable, stimulating, encouraging, and empowering students to participate actively, providing ample room for initiatives, imagination, and freedom in line with their learners' abilities, interests, skills, and physical and psychological growth (Kemendikbud, 2016). From 'students are instructed' to 'learners to find out' is one of the learning concepts used. By the learning theory thinking plays an significant role in the ability to think objectively and solve problems.

The reasoning is a rational and systematic method of focusing on measurable empirical facts in the form of knowledge to draw conclusions (Kemendikbud, 2015). The reasoning is a way to draw conclusions and test a true or invalid conclusion, a process of thinking which connects facts which are known to lead to a conclusion (Suharnan, 2005). Schunk (2012) notes that reasoning refers to the mental processes involved in producing logical arguments and analyzing them. Fisher (2009) said justification is the reasons for providing a reason to support a view. Shadiq (2004) states that reasoning is an action, method, or thought operation to draw conclusions or make a new argument that is right based on certain assumptions that have been proved or believed to be true before. The rationale for the school curriculum is the basis of a broad variety of topics (Van De Walle, 2008). Reasoning creates insights from the mind, consistency, and firmness, and requires problem-solving to justify why something happened or what will happen.

Reasoning implication for learning the following: (1). Provide a representation of metaphors to students. Readings that contain concrete analogies given to students before the reading that contains teaching will help to learn from the intended reading, (2). Ask students to make statements during problem-solving. Verbalization of the mind during 
problem-solving can help bring up solutions to problems from learning, (3). Use questions. Ask students questions that enable them to practice the concepts they have learned, (4). Give an example. Give examples that show the application of problem-solving strategies, (5). Coordinate ideas. Show how production and knowledge are related to each other and in what circumstances it can be applied, (6). Use small groups. Learning in small groups can help in developing problem-solving skills.

Based on research conducted by Baig \& Halai (2006), the key finding of their study is that two important factors encourage students to learn rules through reasoning: the teacher asks and provides students with opportunities to justify their thought, and provides students with opportunities to interact with concrete and semi-concrete objects. Research conducted by Sajadi, Amiripour, \& Rostamy Malkhalifeh (2013) reported that students who are able to reflect and reason will find questions on problem-solving easy to understand; the results revealed by the researcher are that problem-solving teaching improves the analytical skills of the teacher, improves problem-solving skills and increases test scores.

Problems can be presented in studying mathematics in the form of story problems, phenomena or incidents, picture diagrams, or puzzles. The problem is then called a problem of mathematics because it includes mathematical concepts. According to Hudoyo and Sutawijaya (Lidinilah, 2008), mathematical problems can be in the form of (1) a transplant problem, (2) an application problem, (3) a process issue, and (4) a puzzle issue. Results from Parjayanti's research (2013) show that learning by inquiry using advanced organizer learning is effective for mathematical reasoning among students. Hypermedia is used to help students answer unanswered questions (Oliver and Hannafin, 1999). Savuanov, \& Ovsyannikova (2014) claimed that open issues are very important because they provide students with the opportunity to make various possible claims of problem-solving questions.

Polya (Lidinilah, 2008) understanding mathematics means working mathematically. And how do we work mathematically? The most important thing is being able to solve mathematical problems. More than that, when thinking about different ways of solving problems, you must have a positive attitude in coping with problems and be able to resolve various types of problems, not just basic problems that can be solved with only elementary school skills, but can also solve more complicated problems in engineering, physics and so on that will evolve in high school. But the basics must start in elementary school. And also I think that the important thing in elementary school is to introduce students to ways to solve problems. Not only to solve various types of problems and not only to be able to do it but also to develop a general approach in addressing and solving problems.

Polya (Lidinilah, 2008) approach to problem-solving comprises four stages of completion, namely: (1) comprehension of the problem; (2) Planning for problem-solving; (3) Carry out preparation of problem-solving; and (4) Looking back at the settlement. Schoenfeld (Goos et.al., 2000) there are 5 phases in solving problems, namely Learning, Evaluation, Discovery, Planning / Implementation, and Verification. Artzt \& Armor-Thomas (Goos et.al, 2000) developed Schoenfeld's problem-solving steps, namely reading, understanding, analyzing, exploring, planning, implementing, and verifying.

\subsection{The centrality of mathematical reasoning in the education of mathematics}

Reasoning is the activity of developing lines of thought or arguments, which may serve a number of purposes such as to convince others or ourselves about certain claims; to solve problems, or to integrate a number of ideas into a more coherent whole. Two important principles for reasoning are first, that the various steps or actions in the framework of reasoning are related to each other (not necessarily analytically or deductively); and second, that there are explanations why one idea follows another and how a variety of ideas come together to form hypotheses or to solve problems (Ball and Bass in Brodie, 2010). Brousseau and Gibel (Brodie, 2010) show that reason is only considered reasonable when the reason is related to the problem constraints or knowledge considered.

\subsection{Justification and Generalization}


The literature demonstrates that the rationale of mathematical reasoning and generalization requires two main processes, namely mathematical practices such as symbolizing, describing, and interacting (Ball; Ball \& Bass; Davis and Maher). The rationale of Kilpatrick et al. (Brodie, 2010) is a central element of logic and providing ample reasons to explain means. Students must be able to justify and clarify concepts to clearly articulate reasons, hone reasoning skills, and improve conceptual understanding. Justification is the key mathematical method that helps mathematicians and mathematics teachers and students to link different ideas and parts of an argument, to provide guarantees for statements and conjectures, to resolve disputes, and to develop new mathematical concepts.

\subsection{Proof in mathematical logic}

Brodie notes that proof is one type of argument and justification, and not all arguments and justifications are formal evidence, and evidence is not always a sufficient reason or explanation for mathematical thought. The proof is an important aspect of mathematical reasoning and must be taught in the mathematics discipline (2010) as a means of inference, argument, and generalization.

\subsection{Creativity and reasoning skills}

A clear refutation of the supremacy of evidence in mathematics comes from mathematics practitioners, who often work intuitively and creatively in pursuit of meaning and understanding. Analytical tasks include study, assessment, evaluation, comparison, and criticism; creative tasks include development, exploration, creativity, and presupposition. Creative and analytical thinking is often viewed as dichotomous, creative and analytical thinking that actually supports one another in mathematical resolution and reasoning, for example, imagining may require some form of contrast, and usually requires some study. Comparing alternative approaches, concepts, and imaginations require purpose and justification; imaginative thinking may help the relationship between previously unconnected concepts, and sometimes it takes the leap of imagination to see the issue from a different viewpoint (Brodie, 2010).

Thus the importance of this study is to describe students' reasoning abilities in elementary schools to provide an overview to the teacher to organize learning. The learning process should be held interactively, fun, challenging, inspirational, and motivating students to actively participate, and providing sufficient space for the initiative, creativity, and independence by the talents, interests, abilities, and physical and psychological development of students. So the reasoning is an important part of making arguments and making conclusions.

\section{Method}

This research methodology is a qualitative analysis that is descriptive. This research explains and analyzes the ability of fourth-grade students to reason mathematically at SD Negeri Tambakrejo 02 Semarang. The data used in this analysis are qualitative data from the results of the questionnaire to explain the statistical reasoning capabilities of the students' classification. The data sources in this study were collected from teachers and students, with the main focus being fourth-grade students as a research subject at SD Negeri Tambakrejo 02 Semarang. Data analysis activities include data reduction, data presentation, and verification of the data.

The instrument used was a questionnaire with the following indicators: knowing meaning, thinking logically, understanding negative examples, thinking inference, thinking systematically, thinking consistently, drawing conclusions, deciding strategies, making reasoning and determining strategy.

\section{Results and Discussion}

Brodie (2010) has visited hundreds of classrooms around the world where students are asked to work on mathematical problems in silence, never talk about ideas or shape relationships, and connections between ideas; most students hate mathematics and release 
subjects as quickly as possible. Students don't get the most beneficial way of learning, but they don't get access to real and working mathematics either. The reasoning is an activity of thinking in developing arguments to convince others of certain statements or in solving problems or to integrate ideas in problem-solving (Brodie, 2010: 14). The reasoning is a logical and systematic thought process of empirical facts that can be observed to obtain conclusions in the form of knowledge (Kemendikbud, 2016). The reasoning is a way to draw conclusions and determine a true or false conclusion, a method of thought linking known facts to a conclusion (Suharnan, 2005: 157).

The results of this research data are to measure students' reasoning abilities based on ten aspects of reasoning, namely: (1) understanding meaning (2) thinking logically (3) understanding negative examples (4) thinking deduction (5) thinking systematically (6) thinking consistently (7) drawing conclusions (8) determining the method (9) making a reason (10) determining the strategy. The findings of this study are as follows:

Tabel 1. Research Result on Students Reasoning Aspect

\begin{tabular}{lcc}
\hline \multicolumn{1}{c}{ Reasoning aspect } & Research result & Category \\
\hline Understanding Meaning & $36,25 \%$ & Low \\
Thinking Logically & $37.5 \%$ & Low \\
Understanding Negative Example & $31.1 \%$ & Low \\
Thinking Deduction & $17,05 \%$ & Very Low \\
Thinking Systematically & $18,15 \%$ & Very Low \\
Thinking Consistently & $31,65 \%$ & Low \\
Drawing Conclusion & $24,3 \%$ & Very Low \\
Determining Method & $49,85 \%$ & Low \\
Making Reason Determining Strategy & $34,85 \%$ & Low \\
\hline
\end{tabular}

Based on the data in Table 1, the data from the findings of the mathematical reasoning research showed that $36.25 \%$ in the reasoning dimension 'understood the meanings' in the lower category, the reasoning aspects 'logical thinking' included $37.5 \%$ in the lower category, the reasoning aspects 'understood the negative examples' in the lower categories with $31.1 \%$. The reasoning aspect of 'systematic thinking and making excuses' included in the very low category with a percentage of $18.15 \%$; the reasoning aspects 'thinking consistently' included in the low category with a percentage of $31.65 \%$; the 'drawing conclusions' aspect included in the very low category with a percentage of $24.3 \%$; the 'determining method' aspect. Yumiati \& Noviyanti (2017) Work shows that directed inquiry learning is more effective in achieving and improving student participation and understanding compared to traditional learning. Reasoning and Mathematics The group student of traditional learning has a higher proportion of group student or directed inquiry learning. Improving group student mathematics reasoning of directed inquiry learning values 0.33 on the middle level, while improving mathematics representation of group student of traditional learning values 0.19 on the lower category. The sum of enhancement on mathematics The group student representation of the directed inquiry learning is 0.41 on the medium level, and the enhancement on mathematics The group student representation of traditional learning is 0.26 on the small category.

Research result from Priatna (2003) suggested that the level of reasoning ability (analogy and generalization) of junior high school students was small, which was only 49 percent of the ideal score. Likewise, the research result of Napitupulu (2011) reported that students' ability to reason absolutely mathematically is still classified as a lower level. Explanation on model, fact, character, relationship, or current pattern was provided by the lowest achievement of reasoning ability on the dimension. From the results of the research above shows that to teach students reasoning skills can not be done with conventional learning models. Serlina \& Leonard (2019) her research shows that the average value of students who learn to use the treatment interaction learning model (ATI) with forced learning 
tasks and strategies is higher than the average value of students who learn to use conventional methods. Based on the findings of hypothesis testing indicates that there is an effect of aptitude therapy influencing (ATI) learning style with task learning approaches and placed on students' mathematical reasoning abilities.

Susanti \& Rustam (2018) research data analysis obtained this as follows: (1). Students' mathematical reasoning skills are found in the lesser category after studying with the RME, PBL and Direct students 'learning models' mathematical reasoning skills are in the appropriate category before being taught with RME, PBL, and direct studying models. The mathematical reasoning skills of the students improved are in the medium category; (2). There is an improvement in the mathematical reasoning skills of the students after being taught using the RME, PBL and Direct learning model; (3). The mathematical reasoning skills of students taught using the learning model RME are not significantly different from those taught by the learning model PBL; (4). There is a disparity in the efficacy of the learning model in developing the mathematical reasoning skills of the students, which are taught more efficiently using the RME learning model than those taught using a direct learning model; (5). The mathematical reasoning skills of students taught using the PBL learning model are more successful than those taught using the direct learning model; (6). During the learning process, student activities using the RME learning model and the PBL learning model show that the students are very involved.

Jufri, Setiadi, \& Sripatmi (2016) Results from this study showed that 95.5 percent of students had low reasoning ability and were graded as concrete and transitional reasoners. The group of formal operational reasoner was only reached by a few students (4.5 percent). In addition, major variations in reasoning skill of the respondent appeared between the students in the third and fifth semesters, as well as students in the four study programs.

\subsection{Understanding Definition}

In this study understanding definition is the ability of students to define concepts, identify problems, and then provide examples that are in accordance with the concepts. From the table above it appears that aspects of understanding meaning are in a low category, thus the ability to identify and reflect on what was previously understood is low. KBBI online (accessed on 25 July 2019) defines meaning as a description or knowledge of something in mind. The ability to identify and reflect on what has been previously understood. Understanding that is not just from the definition but it is necessary to identify problems or statements related to the material submitted. Identifying the elements that are known and asked. So that in a certain statement it can be concluded that the statement is discussing a topic of material which will later be known that the statement is the understanding of one of the materials being worked on. The study results (Sangila, Safaria, Rahayu, \& Asran: 2019) suggest that teachers be given special attention to students who have impulsive cognitive style, often giving practical questions, steps to answer them, and guiding them so they don't hurry to solve the problem.

\subsection{Logical Thinking}

Sumarmo (2012) says logical thinking involves logical reasoning and other mathematical tasks, namely: logically understanding, linking, communicating, and problemsolving. The analysis shows logical thinking has a wider scope than logical reasoning. As for mathematical logical thought, this also demonstrates that students were unable to think according to the rules of logic, based on structure, classify, categorize and interpret numbers in the correct order, and have sharpness in speculating using their logical skills. Hartono, Saputro, \& Fitriawan (2019) the study results showed that the application of the blended learning model to logic and mathematical reasoning could increase. So it can be inferred that a blended learning model can be used to enhance logical thinking. As'ari, Basri, Purwanto, \& Sisworo. (2019) Research reveals that: (1) the critical thinking abilities of junior high school students were in a low category; (2) the assessment, interpretation, and self-regulation of sub-skills were the lowest critical thinking sub-skills learned by students relative to other critical thinking sub-skills. 


\subsection{Understanding Negative Examples}

In understanding negative examples here is understanding and distinguishing which are not included examples of a particular material. In addition, if you refer to this understanding, it can be said that a simple understanding of the ability to distinguish between examples and not examples

In the aspect of understanding negative examples is in a low category, they have not been able to understand and distinguish which are not included in the examples or the understanding of a particular material. Also, if you refer to this understanding, it can be said that a simple understanding of the ability to distinguish between examples and not examples.

\subsection{Make Reasons and Determine Strategy}

In solving questions or problems that use reasoning, here we need evidence to justify an answer that is put forward in the form of a reason. For example in a statement, how the statement can be said to be true or false, then here a process of thinking and reasoning is needed from what is known and understood from the statement and then conclusions drawn in the form of the right reasons. Suprana (2013: 68) states that the reason is the process of delivering conclusions from data. Reasons consist of evidence (data), demands (conclusions), and thoughts that justify the movement towards conclusions

The aspect of creating explanations and evaluating strategies in the low category indicates that there is still a need to improve the capacity of students to solve problems using some stages. This is in line with what was expressed by Shinha (Shinha, 2018) that students need to be improved in the capacity of reasoning to prove mathematics or problem solving, offering students wide opportunities to do stages of thought in order to provide explanations for new assumptions or claims. In keeping with the results of Kusumawardani's research (Kusumawardani, 2018), which notes that mathematical reasoning can improve mathematical literacy. The logical reasoning abilities of the students are improved by assignments that can practice reasoning for the students.

The study results, it revealed the reasoning ability of the students in the low group which is the principle of practical learning by Ausubel. Knowledge may be conveyed to students at the first level of learning in the form of 'acceptance learning' which introduces knowledge in the final form or in the form of 'discovery learning' which allows students to find in part or all of the material to be learned by themselves. Students in the second level attach or add the information to the knowledge they already have; substantive learning is present in this case. Learned knowledge is openly decided by the students. The students then associate the new knowledge with their own cognitive structure. For instance students are asked to find a square's property. Students may find out for themselves the characteristics of the square by comparing already known information, such as the properties of a rectangle. Therefore the learning model must be established which can enhance the reasoning of the students. The learning process in educational units should be conducted interactively, encouraging, enjoyable, stimulating, empowering students to actively participate, and providing sufficient space for projects, imagination, and freedom by the skills, interests, and physical and psychological growth of students. Each education unit conducts learning planning, implements the learning process and evaluates the learning process to improve the efficiency and effectiveness of graduates' competencies (Kemendikbud, 2016).

The findings of this study are confirmed by research conducted by izzah and azizah (2019) which state mathematics learning is included in the excellent category with a percentage of 87.5 percent, mathematical reasoning classification data obtained a percentage of 22.5 percent in terms of comprehension understanding, 50 percent in aspects of logical thinking, 15 percent in aspects of understanding negative examples, 17.5 percent for aspects of deduction thought, $17.5 \%$ for aspects of systematic thinking, $30 \%$ on aspects of consistent thinking, $12.5 \%$ on aspects of drawing conclusions, $22.5 \%$ on aspects of determining strategy, and lowest results by $10 \%$ for thought aspects making excuses, and the highest percentage of $52.5 \%$ in the aspect of reasoning determines the method. Overall, the percentage is $25 \%$ with a low category. 
Though research conducted by Nashihah (2019) shows that mathematics learning is included in the good category with a percentage of 67.5 percent, mathematical reasoning classification data obtained a percentage of 50 percent as far as reasoning is concerned understands the meaning in the low category, logical reasoning in the thought category is very poor with a percentage of 25 percent, understood. In respect to the formal logic and making arguments included in the low category with a percentage of $38.8 \%$, the clear thought factor included in the low category with a percentage of $33.3 \%$, the fascinating factor assumptions included in the low category with a percentage of $36.1 \%$, the approach included in the quite low category.

Putri's research results (2019) showed overall the percentage results with a small category were 35.55 percent. Aspects of logic included in the low category with a 33.3 percent percentage, inference analysis aspects included in the low category with a 36.7 percent percentage. Hidayatullah (2019) Research Results The reasoning skill of students with middle requirements hits 55 percent. Research conducted by Arianto, Sulianto, \& Azizah (2019) demonstrates the capacity of students to reason in lesser categories in terms of multifaceted content and two-dimentional figure. Hidayati (2013) notes that mathematical reasoning's low capacity is thought to be triggered by the emphasis on learning in the classroom that still focuses on the skills of working on the problem (drill), so it does not provide opportunities for students to develop their own knowledge.

Nashihah, Sulianto, \& Untari (2019), Izzah \& Azizah (2019) their work shows that the mathematical reasoning skills of students are in the low category, based on observations made at the Tambakrejo 02 Elementary School, there are still many students of the fourth grade who earn repeat scores under the KKM by 60 points. The teacher is the only learning outlet for the students. Learning which involves reasoning has not been applied widely. Students' ability to solve problems using logic is still weak when the teacher gives questions that require high-level thinking that many students are unable to understand the purpose of the issue of the story and were unable to solve the problems found in the case. Students also tend not to like math because students consider mathematics as a difficult subject, so students find it difficult to think higher in reasoning questions that use reasoning in their completion. While research conducted by Hidayatullah, Sulianto, \& Azizah (2019) shows that students' reasoning skill are in the moderate category.

Hidayati (2013); Arianto, Sulianto, \& Azizah (2019); Nashihah, sulianto \& Untari (2019); Izzah \& Azizah (2019); Hidayatullah, Sulianto, \& Azizah (2019) measure the ability of reasoning using indicators to have comprehension, think logically, understand negative examples, think deduction, think systematically, think consistently, draw conclusions, determine methods, make reasons and determine strategies.

Zubainur, Jannah, Syahjuzar, \& Vello (2020) Results indicated that the mathematical reasoning skills of the students are increasing through the Discovery Learning Model. The result of this research is that applying the Discovery Learning Model will improve the mathematical reasoning capabilities of the students. The teacher should expand the application of the learning model to other mathematical material in the hope that it can improve students' mathematical reasoning abilities. Lestari, Hartono, \& Purwoko (2016) concluded that learning open-ended approached mathematics affects students' mathematical reasoning. Research findings (Napitupulu, Suryadi, Yaya, Kusumah: 2016) show that adopting PBL in schools is a reasonable choice for students to obtain their high-level thinking skills, particularly schools with medium or high-level students. The results of Saleh, Prahmana, Isa \& Murni (2018) showed the achievement and progress of the students' Mathematical Reasoning Ability in PMRI method learning mathematics is better than traditional learning. The REACT techniques can be implemented by Sari \& Darhim (2020) to build a mathematical representation, reasoning, and temperament capacity that actively engages students. REACT strategy implementation runs smoothly and gets positive feedback from the students. The implementation of REACT approaches should be conducted sustainably so that the learning targets can be met through the incorporation of various capable mathematical skills. Rasmussen \& Marrongelle (2006) RME instructional design is to inform the creation of a sequence of assignments where students develop important 
mathematical ideas and methods through solving a series of connected and challenging problems thereby increasing student reasoning. Huda, S. \& Jermsittiparsert, K., Kharisma, H., N., Qoma, I. (2020) mathematical reasoning ability of students has increased more effectively when the learning process applies the Problem Based Learning models.

Thus the students' reasoning ability is weak, students have not been able to think logically to create comparisons between empirical evidence and the problems they face so that they cannot draw conclusions, students have not been able to make claims in the thought process so that new hypotheses are based on facts, learning models need to be created to enhance mathematical reasoning.

\section{Conclusions}

Based on the results of the review of reasoning classification, as follows: $36.25 \%$ 'understood the meaning' in the low category, 37.5\% 'logical thinking' in the low category, $31.1 \%$ 'understood the negative example' in the low category, $17.05 \%$ 'thought deduction' in the category very low, $18.15 \%$ 'thought systematically' in the category very low, $31.65 \%$ 'think consistently' in low category, 34.85\% 'make excuses and determine strategies' in low category, $49.85 \%$ 'determine method' in low category, and $24.3 \%$ 'draw conclusions' in low category. Thus the reasoning ability of students is low, students have not been able to think logically to make connections between empirical facts and the problems faced so they are not able to draw conclusions, students have not been able to do the thinking process to make arguments so that new statements are based on facts, students have not been able to make new arguments or statements based on facts, Learning models need to development to enhance the reasoning skills of elementary school students.

\section{References}

Arianto, A., S., Sulianto, J., Azizah, M. (2019). Analisis kemampuan penalaran matematis siswa kelas IV SD N Gayamsari 02 di kota Semarang. Jurnal Sinektik, (2)2, 136-149.

Ariyana, Y., dkk. (2019). Buku pegangan pembelajaran beorientasi pada keterampilan berpikir tingkat tinggi. Jakarta: Kementerian Pendidikan dan Kebudayaan.

Baig, S \& Halai, A. (2006). Learning Mathematical Rules With Reasoning. Eurasia Journal of Mathematics, Science and Technology Education. 2, (2), 15-33.

Basri, H., Purwanto., As'ari, a., R., \& Sisworo. (2019). Investigating Critical Thinking Skill of Junior High School in Solving Mathematical Problem. International Journal of Instruction. 12(3), 745-758.

Badan Pengembangan dan Pembinaan Bahasa, Kemendikbud. (2016).KBBI Daring. Diakses 25 Juli 2019. https://kbbi.kemdikbud.go.id/Cari/Index.

Brodie, K. (2010). Teaching mathematical reasoning in secondary school classrooms. London: Springer.

Fisher, A. (2009). Berpikir Kritis Sebuah Pengantar. Jakarta: Erlangga.

Goos, et.al. (2000). A Money Problem: A Source of Insight Into Problem Solving Actioan. Queensland: The University of Queensland [online]. http://www.cimt.plymouth.ac.uk/journal/pgmoney.pdf.

Hannafin, M., Land, S., \& Oliver, K. (1999). Open-ended learning environments: foundations, methods, and models. Instructional design theories and models: Volume II p. 115140).

Hartono, Saputro, \& Fitriawan. (2019). Penerapan Model Pembelajaran Blended Learning Pada Mata Kuliah Logika Dan Penalaran Matematika. Jurnal Pendidikan Matematika Indonesia, 4(2), 84-89.

Hidayati, K., N. (2013). Peningkatan kemampuan penalaran matematika siswa melalui model pembelajaran learning cycle " $5 \mathrm{e}$ " dengan menggunakan alat peraga pada siswa kelas V SD N Mudal 03 boyolali. Diakses dari http://eprints.ums.ac.id/23192/17/11. naskahpublikasi.pdf

Hidayatullah, M., S., Sulianto, J., Azizah, M. (2019). Analisis Kemampuan Penalaran ditinjau dari Kemampuan Pemecahan Masalah Matematis. Thinking Skills and Creativity Journal. 2(2), 93-102. 
Hino, K. (2007). Toward the problem-centered classroom: trends in mathematical problem solving in Japan. ZDM Mathematics Education Journal. 2007 (39): 503-514. DOI 10.1007/s11858-007-0052-1.

Huda, S., Kharisma, H., N., Qoma, I., \& Jermsittiparsert, K. (2020). How Mathematical Reasoning Abilities can be improved?: A Study Case at Islamic Boarding School. Desimal: Jurnal Matematika,3(1), 1-6.

Izzah, K., H., Azizah, M. (2019). Analisis Kemampuan Penalaran Siswa dalam Pemecahan Masalah Matematika Siswa Kelas IV. Indonesian Journal Of Educational Research and Review, 2(2). 210-218.

Jufri, A., W., Setiadi, D., \& Sripatmi. (2016). Scientific Reasoning Ability Of Prospective Student Teacher In The Excellence Program Of Mathematics And Science Teacher Education In University Of Mataram. Jurnal Pendidikan IPA Indonesia, 5 (1), 69-74.

Kementerian Pendidikan dan Kebudayaan RI. Kamus Besar Bahasa Indonesia Daring. Diakses dari https://kbbi.kemdikbud.go.id.

Kemendikbud. (2014). Peraturan menteri pendidikan dan kebudayaan nomor 103 tentang Pembelajaran Pada Pendidikan Dasar dan Menengah. Jakarta: Kementerian Pendidikan dan Kebudayaan.

Kemendikbud. (2015). Materi Pelatihan Guru Implementasi Kurikulum 2013 SD Kelas VI. Jakarta: Badan Pengembangan Sumber Daya Manusia Pendidikan dan Kebudayaan.

Kemendikbud. (2016). Peraturan menteri pendidikan dan kebudayaan nomor 22 tentang Standar Proses Pendidikan Dasar dan Menengah. Jakarta: Kementerian Pendidikan dan Kebudayaan.

Kusumawardani, D., R., Wardono, \& Kartono. (2018). Pentingnya Penalaran Matematika dalam Meningkatkan Kemampuan Literasi Matematika. PRISMA, Prosiding Seminar Nasional Matematika. Unnes.

Lestari, N., Hartono, Y., \& Purwoko. (2016). Pengaruh Pendekatan Open-Ended terhadap Penalaran Matematika Siswa Sekolah Menengah Pertama Palembang. Jurnal Pendidikan Matematika, 10(1), 81-95.

Lidinillah, D., A., M. (2008). Strategi Pembelajaran Pemecahan Masalah Di Sekolah Dasar. Jurnal Pendidikan Dasar. http://file.upi.edu/direktori/kdtasikmalaya/dindin_abdul_muiz_lidinillah_(kd-tasikmalaya)$197901132005011003 / 132313548 \% 20-\% 20-$

dindin\%20abdul\%20muiz\%20lidinillah/pembelajaran....pdfvi.

Marsound, D. (2005). Improving Math Education in Elementary School: A Short Book for Teachers. Oregon: University of Oregon. [online]. http://darkwing.uoregon.edu/.../EIMath.pdf

Napitupulu, E. (2011). Pengaruh Pembelajaran Berbasis Masalah atas Kemampuan Penalaran dan Pemecahan Masalah Matematis serta Sikap terhadap Matematika Siswa Sekolah Menengah Atas. Unpublished Dissertation. Bandung: Program Pascasarjana UPI.

Napitupulu, E., E., Suryadi, D., \& Yaya, S. Kusumah. (2016). Cultivating Upper Secondary Students' Mathematical Reasoning-Ability and Attitude Towards Mathematics Through Problem-Based Learning. Journal on Mathematics Education, 7(2), 117-128.

Nashihah, D., Sulianto, J., \& Untari, M., A., U. (2019). Klasifikasi Kemampuan Penalaran Matematis Siswa Kelas IV Sd Negeri Tambakrejo 02 Semarang. Indonesian Journal Of Educational Research and Review. 2(2). 203-209.

National Council Teacher Mathematics. (2000). Principles and Standards for School Mathematics. Reston: NCTM.

Parjayanti, A. D., \& Wardono. (2013). Studi komparasi model pembelajaran antara inkuiri dan advance organizer untuk penalaran matematis. Jurnal Kreano, 4(1), 64-72.

Priatna, N. (2003). Kemampuan Penalaran dan Pemahaman Matematika Siswa Kelas 3 Sekolah Lanjutan Tingkat Pertama Negeri Kota Bandung. Unpublished Dissertation. Bandung: Program Pascasarjana UPI. 
Putri, D., K., Sulianto, J. \& Azizah, M. (2019). Kemampuan Penalaran Matematis ditinjau dari Kemampuan Pemecahan Masalah. International Journal of Elementary Education. 3(3), 351-357.

Rasmussen, C., \& Marrongelle, K. (2006). Pedagogical Content Tool: Integrating Student Reasoning and Mathematics in Instruction. Journal of Research in Mathematics Education, 37(5), 388-420.

Sajadi, M., Amiripour, P. \&Malkhalifeh, M. R. (2013). The Examining Mathematical Word Problems Solving Ability under Efficient Representation Aspect. Journals mathematics Education Trends And Research, Vol. 2013. ISPACS International Scientific Publications And Consulting Services.

Saleh, M., Prahmana, R.C.I., Isa, M., \& Murni. (2018). Improving the Reasoning Ability of Elementary School Student through the Indonesian Realistic Mathematics Education. Journal on Mathematics Education, 9(1), 41-54.

Sangila, M., S., Safaria, S., A., Rahayu, I., R., \& Asran. (2019). Penalaran Matematis antara Siswa Laki-Laki dan Perempuan yang Bergaya Kognitif Impulsif dalam Memecahkan Masalah Matematika. Jurnal Al-Ta'dib, 12(1), 83-98.

Sari, D.P., \& Darhim. (2020). Implementation of react strategy to develop mathematical representation, reasoning, and disposition ability. Journal on Mathematics Education, $11(1), 145-156$

Savuanov, I \& Ovsyannikova, I. (2014). Paradigm of the "open-approach" method in mathematics teaching: Focus on mathematical problem solving. International Reviews on Mathematical Education Journal, 23(2), 32-37.

Schunk, D. H. (2012). Learning Theories an Educational Perspective. Yogyakarta: Pustaka Pelajar

Serlina \& Leonard. (2019). The Role of Aptitude Treatment Interaction Instructional Model with Task and Forced Instructional Strategy on Student Mathematical Reasoning Ability. Journal of Instructional Development Research, 1(1), 1-12. DOI: http://dx.doi.org/10/30998/jidr.v1i1.200

Shadiq, F. (2008). Penalaran, Pemecahan Masalah dan Komunikasi dalam pembelajaran matematika. Yogyakarta: Departemen Pendidikan Nasional Pusat Pengembangan Penataran guru (PPPG) Matematika.

Shinha, D. (2018). Progressions In Reasoning In K-12 Mathematics. https://arxiv.org/pdf/1812.11947.pdf

Suharnan. (2005). Psikologi Kognitif. Surabaya: Srikandi.

Sumarmo, U. (2012). Kemampuan dan disposis berpikir logis, kritis, dan kreatif matematik (eksperimen terhadap siswa sma menggunakan pembelajaran berbasis masalah dan strategi think-talk-write). Jurnal Pendidikan Matematika, 17(1).

Suprana, J. (2013). Alasanologi. Jakarta: Elex Media Komputindo.

Susanti, G., \& Rustam, A. (2018). The Effectiveness of Learning Models Realistic Mathematics Education and Problem Based Learning toward Mathematical Reasoning Skills at Students of Junior High School. Journal of Mathematics Education, 3 (1), 3339.

Yumiati \& Noviyanti, M. (2017). Abilities of Reasoning and Mathematics Representation on Guided Inquiry Learning. Journal of Education and Learning. 11(3) pp. 283-290.

Van De Walle, J. A. (2008). Pengembangan Pengajaran Matematika Sekolah Dasar dan Menengah Jilid 2. Jakarta: Erlangga.

Zubainur, C., M., Jannah, R., Syahjuzar, \& Vello, A. (2020). Kemampuan Penalaran Matematis Siswa melalui Model Discovery Learning di Sekolah Menengah Aceh. Journal of Scientific Information and Educational Creatifity, 21(1), 148-170. 